\title{
Paul Gauguin and the Quest for World Spirituality
}

\author{
Iswahyudi \\ Universitas Negeri Yogyakarta, Indonesia \\ Email: iswahyudi@uny.ac.id
}

\begin{abstract}
Paul Gauguin was born in Paris, France on June 7, 1848. The dynamics of his life journey greatly motivated his search for something deeper and more meaningful in his life and work. Gauguin's disillusionment with the bourgeois society in his environment and his desire to create his art works encouraged his decision to devote himself totally as an artist, especially outside his environment. He traveled from one region to another outside Europe. This experience will influence his development as a painter. The trips that Gauguin often undertook were influenced by his work as well as seeking broader and deeper experiences. As a European he sought a "primitive" lifestyle that was neither tangible nor considered "exotic". He is looking for geographic answers to his professional and personal searches while living in Tahiti. By examining his personal life, it is known that Gauguin's wandering led him to a deeper spiritual life, which is reflected in his works and writings. In order to understand the expression of spirituality in his work, we will examine several major works by Gauguin that clearly depict images of Buddhism and other Eastern religions.
\end{abstract}

Keywords: Paul Gauguin; post impressionist; spirituality; Tahiti; Eastern religion

\section{Introduction}

Paul Gauguin is a great painter and writer of all time. In this case, writing about the journey of his life and the results of his paintings have been done a lot. Even so, writing on this matter will continue to be done and of course it is hoped that in the future it will produce new interpretations based on the written sources that are found. In this paper there are more religious references to Gauguin's paintings than previous writers have provided. Gauguin's self-portrait shows that there are references to religions ranging from Jewish, Christian traditions to Sufi mysticism. The depiction of himself by manifesting his existence in various religious figures and spirituality figures is a proof of the foregoing.

Gauguin and his interest in world religion, identity and spirituality added to the increasingly diverse works of art he produced. This paper also examines the relationship between his religious works by Pont-Aven, Tahiti and Marquesas in an attempt to present a more coherent reading of Gauguin's work of art or oeuvre. In doing so, we will look at several things that relate to Gauiguin's works thematically rather than chronologically. Gauguin painted religious landscapes and self-portraits throughout his career and has never been fixated on a particular person or religion so that the topic deserves to be read thematically. In writing this does not address the problems of Gauguin's personal beliefs or attempt to extrapolate his religious tendencies from his paintings. The aim is to determine how these religious paintings and self-portraits work together and how an analysis of their religious themes can contribute to a greater sense of continuity in Paul Gauguin's works.

Writers have frequently discussed certain aspects of spirituality in Gauguin's work, but have retained the chronological reading or have tackled work or religion piecemeal. For example, Deborah Silverman was deeply interested in the work Gauguin produced during the 
1880s, her friendship with van Gogh, and her relationship with Catholicism (Silverman, 200). But he was also interested in modernism and religion in France. Stephen Eisenman in Gauguin's Skirt writes about the artist's Tahitian period, and devotes a chapter to post-colonial Tahiti and Tahitian popular response to Gauguin (Eisenman Ed., 1997). Both ends of this spectrum are complemented by the work of other scholars on certain aspects of Gauguin's work. The less orthodox highlights Gauguin's relationship to Buddhism, Hinduism and the Cabala. In this respect there is evidence of Gauguin's interest in esotericism and Egyptian art (Jirat Wasiutynski, 1987:22-28).

Each of these authors presented plausible arguments and brought plenty of material for studying Gauguin's art; However, the narrow scope and chronological boundaries of each of these studies prevent these different aspects from coming together in one place. In this paper, we will discuss solely about Gauguin's art which unites depth with breadth under the rubric of spirituality and religion from France to Marquesas. The purpose of this paper is to look at the greater complexity of Gauguin's interest in spirituality and to demonstrate the consistency of that interest in spirituality.

Gauguin's links to theosophers and his references to Buddhism, Hinduism, Sufi mysticism, and Tahitian religion in his paintings are a product of individual interests as well as a product of colonialism. The relationship between European and Tahitian culture adds a level of complexity to Gauguin's work from the Tahitian period and provides a framework for interpreting his art. Although Gauguin fled Europe and the European settlement of Tahiti, he drew attention to his European identity in a foreign colony because of his status, appearance, and relationship with the natives. Colonial constructs of racial difference and the desire for difference are what underlie Gauguin's experience and art (Young, 1995: 158).

Her interest in different religions and spiritualities is her main means of portraying other cultures as well as her own. Gauguin's position within and outside of European, Tahitian, and Marquesan cultures must be considered alongside his long inv estment in matters of religion and spirituality. Gauguin's interest in painting religious subject matter and his selfportraits provide argument support for a comprehensive analysis of the themes in Gauguin's works.

\section{Research Methods}

To find out about Paul Gauguin and the search for world spirituality is carried out using historical methods or historical research methods which can be interpreted as a systematic collection of principles and rules intended to assist effectively in gathering resources material from history, in assessing or analyzing these sources critically, and presenting a "synthesis" of the results achieved. This method is qualitative in the form of literature study using written sources of library collections in the form of books, journals, and other printed sources (Garraghan,1957: 33).

As the object in this paper is a painter, of course the works that he produces have a narrative or narrative tendency and are works that contain picture elements that are interconnected to form a unity of message and meaning. Based on this, works of art with these characteristics must be understood as a network or collection of texts. Elements or objects that are interconnected in images are understood as textual units of language that form a kind of sentence, paragraph, or complete composition. This means that the method that must be used is the text analysis method (Saidi et al.,2021: 79). 
Primary and secondary data collection techniques are carried out through research libraries which are carried out by visiting various libraries and agencies that store reference books, articles in magazines and newspapers such as the Taman Ismail Marzuki art complex library in Jakarta, the National Library of the Republic of Indonesia and at the libraries of various Universities and the Academy of the Arts. After the search for written material has been completed, the next step is to select and verify the data and compile it into a writing (Iswahyudi, 2020: 800).

\section{Discussion}

\subsection{Questions about the Origin of Humans}

Emile Durkheim argues that religion is a principle of order that is necessary in the life of individuals and groups. In his book published in 1912, he stated that all religions have the same social function and therefore can never be considered wrong (Durkheim, 1995: 2-4). Durkheim further suggested that there is a common element among all religions which is comparable at the elemental level. Given the similarities and functions of religion in the lives of his followers, including Gauguin himself of different religious beliefs in his work shows that he understands religion as a principle of order in art and in his life. Although Durkheim's thoughtful expression of religion only emerged after Gauguin's death, it should be noted that his initial investigations into the topic began at the same time as the culmination of Gauguin's works.

One common theme among all religions is the need for a story of human origins. Paul Gauguin's concern with stories of human origins has become a pervasive theme in his work s of art. Gauguin, who was indoctrinated into the Catholic faith as a child, became familiar with the biblical narrative of Adam and Eve, setting the backdrop for his allusion to the Christian Genesis scene in Self Portrait with Halo and in his Tahitian Eves painting. Her interest in human origins also explains her desire to find a place closer to the beautiful paradise. His attempts to answer this question of origins eventually led him to Tahiti. Gauguin traveled to Tahiti with expectations shaped by previous travelers' accounts of Tahitian beauty, savagery and women. Relying on allusions of previous travel literature, particularly Pierre Loti's (Julien Viaud) The Marriage of Loti and J.A. Moerenhout, Voyages aux îles du Grand Océan, where Gauguin recounts his romantic experiences on the island of Tahiti (Loti n.p). As was common with nineteenth-century artists and intellectuals, Gauguin had a desire to return to an earlier period of civilization where mystical rituals and ancestor worship provided a mystical rather than rational system of meaning. Durkheim's own desire to arrive at a basic form of religion led him to write about indigenous Australians and the "simplest" type of religious belief system (Gauguin, 1947: 9). His contributions to anthropology and sociology are reminiscent of Gauguin's own identity as that of an ethnographer interested in Tahitian beliefs and culture. Gauguin wanted Noa Noa to function as a type of explanatory text for the French public to his paintings and Tahitian life and religion.

It turned out that Tahiti had disappointed Gauguin because of his culture, which was no more savage than that of Europe. He regrets that the people of Papeete are imitating European customs, fashions and civilization. Although Gauguin went to Tahiti as a government representative tasked with documenting the people and their way of life, he soon left the capital to live among the natives and away from Europeans (Gauguin, 1947: 9). He did not identify with the Europeans in Tahiti, but he was certainly not a native, and this placed him as an outsider in everything. There he painted to ward off disappointment and resignation. The resulting images use luminous colors and sparkling surfaces that are more 
reflective of existing reality than the projected dream of the exhaustion of European civilization. The colonial uneasiness that accompanied political differences was behind Gauguin's choice to distance himself and showed that he was following his predecessors who were rebellious from standard colonialist notions of decency (Godeau, 1989: 118-129).

The mixed titles of his work show the uncertainty of his position as an insider and an outsider in Tahitian society. It is known that Gauguin never mastered the Tahitian language or diction, limiting his ability to communicate with Tahitians in their native language. It also prevents assimilation into Tahitian culture and a certain degree of involvement with important aspects of Tahitian life. Nevertheless, he used the crude Tahitian title for Tahitian paintings as a way of establishing and promoting the authenticity of the subject matter to French audiences in Paris.

Gauguin painted several images of bonfire ceremonies that coincided with Emile Durkheim's description of the Warramunga ritual based on records of religious ceremonies. Upaupa (1891) and Fire of Joy (1891) which are Gauguin's two visual responses to Tahitian religious practice. Upaupa, which in Tahitian means dancing or playing, was previously entitled La Danse du Feu, which indicates that this is part of the ritual of walking on the Tahitian fire. This interpretation was then put forward by the figure of a white-robed priest. Walking on the fire was still in practice and familiar to the invaders at the time of Gauguin's arrival, meaning that even though he did not witness the event in person, it still deserves to be incorporated into his painting as a distinctively Tahitian religious ritual (Biddle, 1968: 111). This type of ritual was different from the routine practice of Christian worship and more akin to the mystical spirituality of the peasants he witnessed in Brittany, making it a subject of interest to people in France. The tree branch that divides the canvas diagonally recalls the figurative Gauguin used in Vision after the Sermon to awaken the supernatural realm. This compositional connection equates the two works as representing a type of religious vision (Eisenman Ed., 2007: 278).

Gauguin painted the Fire of Joy at the same time, again using the Tahitian ritual as the subject. The fire scene with the Tahitian people shows Gauguin's desire to understand and experience Tahitian ritual and religion and document them for the French public. A distant sunset or sunrise view, Fire of Joy draws on a practice documented by the anthropologist J.L. Young in 1925 where the Tahitians burned a charcoal fire near the altar from sunset to sunrise for the purpose of walking on fires and performing ceremonies. Eisenman and Stuckey assumed that the painting had no figures and noted the difference from Gauguin's other works of that time period (Eisenman Ed., 2007: 278). The figures appeared as black lines in the distance, further showing Gauguin's own understanding of himself as an outsider. Even Gauguin's self-portrait represents the artist, both in his studio and in religious circles. He included himself in Christian themed paintings, Vision after Sermon, Self-Portrait with Halo, and Self-Portrait, Nearing Golgotha. Gauguin, however, never positioned himself in the Tahitian scene, everyday life, or religious ceremonies. His choice of immersing himself in Christian work and breaking away from Tahitian paintings attests to his role as an ethnographic observer. He is a witness and not a participant.

Upaupa can be considered to represent Tahitian cosmology and the difference between Tahitian and European. Gauguin danced upaupa in France at his farewell party the night before their departure for Tahiti. Judith Gérard, a friend and witness, recalled that Gauguin was overwhelmed by his ferocious instincts, and anticipating the joy that soon returned to his right element, he danced upaupa. The assumption that certain religious behavior is instinctive suggests that Tahitian beliefs and religion are more closely related to 
nature and difficult to control. Gérard's records also reveal Gauguin's French assumptions. The fact returns to its barbaric roots, demonstrating the importance of the alleged primitivism of Tahitian and the origin of the artist in the state. Gauguin did learn about the Tahitian religion and incorporated its elements into his canvases and writings. He claims in Noa Noa that his young vahine served as a spiritual guide and taught him about ancestral spirits and origins.

His interest in human origins was not limited to the similarities between Christian and Tahitian religious traditions but also included myths and theosophical beliefs. Gauguin studied theosophy and concepts of universal origins which enabled him to consider Christianity, Buddhism, and the Tahitian religion as equals, all structured by a single divine creator. In his treatise L'Esprit moderne et le catholicisme, he includes many creation myths and argues that each must be read literally and philosophically in order to appreciate its specific meaning and universality (Zink, 1978: 18).

It is also important to note in light of his preoccupation with human origins that Gauguin began his treatise in 1897, the same year in which he painted his most comprehensive religious and philosophical statement namely Who are we ?, Where are we going?, Where Do We Come From? , Where are we going? (1897) is a mysterious work in Paul Gauguin's artwork due to its size and composition. The painting consists of various scenes and serves as a joint work combining the study of figures, religious imagery and animals, all with in the Tahitian landscape. Gauguin's own titles and religious and cultural positions support the interpretation that the painting is the culmination of his engagement with foreign cultures and religious beliefs.

Gauguin's painting does provide additional clues to viewers but its title is potentially even more confusing. In asking broad philosophical questions about identity, meaning, and the afterlife, Gauguin tries to reconcile the uncertainty of human origin and the destiny of the soul in ways that traditionally stem from one's religious beliefs. Its use of the first person plural places itself as part of an undetermined group and suggests that there is a general answer that goes beyond certain religious affiliations and tends towards a more comprehensive interpretation of the world. Gauguin's curiosity about his existence and involvement with other cultures led him to explore meaning through archetypal religious symbols. Visually, Gauguin includes characters from stories of Christian origin, the Hindu pantheon and the Tahitian religion. Gauguin is familiar with Tahitian cosmology and refers to certain deities in his writing and art, including the figure on the pedestal to the left in the painting "Where did we come from?". Scholars generally assume that this figure is the goddess Hina, whose mystical union with Ta'aroa resulted in the birth of the universe. Gauguin described the idea for a similar painting around that time by depicting a woman who was turned into an idol of heaven (Fisk, 1983: 128).

The reading of the figure as Ta'aroa coincides with the painting's Tahiti setting and especially with the narrative allusion to the union of the sexes. Although there is evidence to read the figure as Ta'aroa, it could easily represent a Hindu male deity. Given Gauguin's propensity to depict two-sex men (especially from non-Western cultures as seen again in Marquesan Man with a Red Cape), the sculpture in the painting may actually represent Krishna. Krishna can take the form of Vishnu and is generally young, which may explain androgynous to this figure (Crooke, 1900: 3). The figure in turn refers to the androgynous main character who takes the fruit from the tree. Krishna can also take the form of a cowherd who plays music and protects his flock, and is therefore correlative with the Greek god Hermes or Apollo. Krishna is usually denoted by the color blue because his name means "the 
black one, the dark one, or the dark blue one" (Crooke, 1900: 28). Assuming this image is meant to be $\mathrm{Ka}$, its role will be as the human incarnation of the Most High, Vishnu. In placing this figure among people of Christian faith, Gauguin emphasized the similarities between the Hindu and Christian divine creators (God and Vishnu) and the incarnations of young, male, and human humans - Krishna and Jesus Christ.

Gauguin's familiarity with Hinduism and the incorporation of Hindu references in other works supports the possibility that this figure was Krishna. Gauguin's preoccupation with stories of origins and his own desire to return to heaven is at the heart of his religious work as well as his self-portrait. His constant search for answers to the first question "where did we come from?" aligned with the possible universal origins that individuals and groups try to achieve through the explanation of religious narratives. This account analyzes the various interests in œuvre Gauguin, including his interests in other cultures and religions and their relationship to ethnographic disciplines. The depiction of figures from Gauguin coincided with his interest in world religions. Where Did We Come From? Is combining figures from Christian, Hindu, Tahitian and Buddhist traditions. The significance of handling all these images together is that it adds a greater level of complexity to Gauguin's painting and provides a model for looking into the multiple layers of meaning in his other works.

\subsection{Interest in Hinduism and Buddhism}

Gauguin's interest in Eastern religions usually enters science in relation to Buddhism and sometimes Hinduism. However, there is one aspect of Gauguin's religious interest that no other scholar has ever mentioned: his awareness of Sufism. I would argue that Gauguin was not only aware of Sufism but painted himself in the guise of a dervish in Self-Portrait with Palette (1894). This lurking is not an overt response to textual or religious sources. Gauguin's friend Aurier in the draft manuscript wrote about the theory of Symbolism (circa 1893) under the title Let us become mystics of art. Examples of Symbolic interest in mysticism support the visual references that appear in Gauguin's self-portrait. The elements, on and off the canvas, support the interpretation that Gauguin refers to certain aspects of Sufism. According to Sufi legend, there was a disciple named Jelāl who met another follower named Shemsu-'d-Dīn. The latter went insane and disappeared without warning, wherein Jelāl adopted "as a sign of mourning for his loss, the drab hat and wide robe of being worn by him the dervish order" (Shemsu'Din Ahmed, 1976: 21).

A dervish's outfit consists of a dark robe and a hat similar to the one Gauguin wore in Self-Portrait with Palette. Gauguin completed the painting after van Gogh's death, which could further attribute the adoption of the dervish role to one of his self-portraits after his friend committed suicide. The background of the painting is an approximation of the background color of Sight after the Sermon, which he paints along with the self-portrait given to van Gogh. There is another work that Gauguin remembers in his choice of color. Eisenman and Stuckey argue that the vermilion background resembles and refers to the SelfPortrait with Halo, as it is about Gauguin painting both works in Brittany (Eisenman Ed., 2007: 316).

The combination of the Christian legend about Jacob and the angel with the Sufi legend of Jelāl is in line with Gauguin's interest in the theosophical beliefs of the symbolists. In an 1888 letter to his friend and friend of van Gogh, Emile Schuffenecker, it read: "So you speak of my terrible mysticism." This commentary shows that Gauguin's interest in mystical religion began during his relationship with van Gogh and Bernard and continued his painting from that year as well as those that followed. Another detail that should not escape the attention of the audience is the orientalization of Gauguin's features, especially his eyes. The 
change in its features may not be obvious unless the painting appears in relation to the photographic source. The difference in accentuation of the artist's eyebrows and curvature of the eyes, as well as the sharpness of the overall features. Gauguin's orientalization is similar to van Gogh's acknowledged modification of his own appearance in the Self-Portrait of a Buddhist monk, which he painted for Gauguin in 1888.

The two artists expressed their interest in understanding Eastern religions and cultures; they talked to each other and with Bernard specifically about mysticism. Gauguin claims that in his self-portrait in Les Misérables with "eyes, mouth, nose, like flowers on a Persian rug, thus symbolizing the symbolic side." The artists' interest in Eastern culture also led to developing friendships with artists from other regions and with similar interests. The hat that Gauguin wore in his Self-Portrait and photos was actually a gift from Czech artist Alphonse Mucha. It was the "Persian sheep hat" remembered by his friend Armand Séguin as part of his favorite outfit at the time that made it look to the Parisians like a big, lavish Magyar, or like Rembrandt from 1635 (Eisenman Ed., 2007:316). The hat is related to Sufism because the origin of the word Sufi is actually from Arabic, "tasawwuf," which translates to "'wearing wool (suf),' pure wool, like Jewish and Christian hermits, like John the Baptist, like Mandaean in Harran or Baghdad" (Churton, 2005: 144). What is even more interesting about the two comparisons of Séguin is his comparison of Gauguin with the "big, luxurious Magyar". Magyar is another name used throughout the nineteenth century for people of ethnic Hungarian ethnicity. They are believed to be related to the Huns, who are considered to be an Asian tribe and speak a non-Indo-European, Turkish language.

Gauguin's choice of Magyar or dervish clothing and his changing appearance coincided with his growing interest in identifying himself as a savage outside of conventional European society and religion. Gauguin considered himself both a savage and a poet. References to mysticism and familiarity with literary traditions help link her costume to the thirteenth-century Persian poet Jalal ad-Dīn Muhammad Rumi. Rumi is known as the mystical poet who dictated the Persian Koran and founded "The Whirling Darvishes" (Lawrence, 2006: 119). Dervish was originally associated with poverty and a monastic lifestyle. Gauguin must have realized the Sufi tradition was most likely due to his friend, Émile Bernard. Bernard trained a student, Ivan Aguéli , later named Shiekh 'Abd al-Hadi Aqhili after converting to Islam, a wandering Sufi by birth The Swede who founded the Parisian Al Akbariyya society and studied all kinds of esoteric and metaphysical traditions, Aguéli was also an anarchist, who was arrested for his links to French anarchists and released in the Thirty Trial in 1894, the year Gauguin completed his self-portrait.

Stéphane Mallarmé's poetry was used to defend criminal suspects, and Mallarmé and psychologist Charles Henry testified at trial as character witnesses for Félix Fénéon, one of thirty. Mallarmé was also one of the Paris literary figures who advanced the career of Gauguin's work and protected him from criticism. Gauguin's self-portrait is either a tacit support for the accused or another opportunity to mediate his identity by again aligning himself with criminals and heretics. Gauguin's relationship to Sufi mysticism and universal understanding of its origins is unclear and likely only superficial. van Gogh wrote about them in a letter to Bernard. He mentions writing about Rembrandt that "just as Socrates and Mohammed had familiar genies," Rembrandt's painting of Christ and the angels is a "metaphysical miracle" (Jansen et al., 2007: 226. 228).

The theosophical belief that all existence originates from one divine creator helps explain Gauguin's own spiritual position. This reference also explains the previous relationship between Rembrandt and Gauguin at a level that goes beyond the concept of the artist as a 
self-painter and a painter of religious subject matter. At this point also after returning from his first stop in Tahiti, Gauguin stayed with a woman whom he called "Anna the Javanese". There is little documentation about their relationship, but he accompanies her to the salon and interacts with her and her group of artist friends. Gauguin's relationship with Anna is part of his style as a savage: he seems to be looking for a woman who is able to show his travel and savage nature to the French public. She confirms her exotic story through her presence as a supposed vahine, symbolizing Teha'amana from Noa Noa. With her pet monkey perched on her shoulder, Anna signed a contract with Gauguin as an interracial and exotic couple on the fringes of society: they dressed in exotic clothes, performed exotic dances, and spent time among exotic artists. After her relationship with Gauguin ended, Anna started modeling for Alphonse Mucha (Danielsson, 1966: 144).

The relationship between these three people and the self-portrait implies a greater sense of artistic agency and gives the work a greater sense of complexity. As can be seen in the interpretations discussed in this chapter, Gauguin's self-portrait proves his desire to establish his own identity through comparisons between himself and others. This comparison links Gauguin's work to the personalities and visual attributes of fellow artists and writers. In order to signify himself, he turns to the space of signs and frames of reference, particularly through the use of religious figures of speech. The Symbolists prove that theosophy and religion provide their art with greater symbolic complexity. Gauguin, Bernard, and van Gogh all shared the same attitude regarding modernism and a desire to escape to what they thought would be a simpler place that had more to do with nature and spirituality. Gauguin took this approach in painting his self-portraits in order to reflexively participate in the construction of his own identity in the space of symbolic representation (Childs, 2001: 113).

\section{Conclusion}

In a comprehensive reading of Paul Gauguin's art based on his own involvement with aspects of spirituality and identity. The diversity and complexity of Paul Gauguin's symbolism does not prevent thematic readings, but rather fits into this particular methodology. By choosing to focus on one particular aspect of his career and work, scholars ignore the rich relationship between parts and the whole. Not only do these parts relate to the whole but with other parts as well, leading to the interdependence of references and symbols in Gauguin's works.

Gauguin's interest in religion, spirituality and philosophy shows that his self-portraits and religious works are a means of answering questions and uncertainties about his personal beliefs and spiritual existence. He takes on other roles and his shifting mode of selfrepresentation in self-portraits, writings, and other works gives viewers and readers a flowing understanding of a man looking for answers to existence's big questions. He wrote that his work was "utterly incomprehensible". These studies attribute their complexity to the use of symbols that transcend the possibilities of a single religion into multiple layers of meaning and reject simpler interpretations.

Gauguin's artistic and theosophical developments spanned his entire career and did not provide concise conclusions in terms of understanding his painting. This study shows that the spiritual aspects of Gauguin's paintings are less comprehensible if they are not seen as individual works but as symbolic parts of a complex and multifaceted whole. It is also important to note that these works are understood as products of the nineteenth century reflecting a shift in European interest to non-European cultures, religions and locales. 
Gauguin's works are directly linked to his engagement with other cultures and belief systems and connect him more closely with past European artists and writers and contemporaries. The complexity of religious paintings and self-portraits is representative of political and cultural circumstances which give him more reference and source material. Cuvre Gauguin acquired a new level of consistency due to his interest in spirituality, giving viewers a wider scope to perceive his paintings as cohesive thematic works.

Paul Gauguin is an artist in constant dialogue with historical and contemporary literature, philosophy and religion. The breadth and the repetition of allusions to the Bible, Thomas Carlyle, Victor Hugo, and Jalal ad-Dīn Muhammad Rumi provide Gauguin's art with a sense of thematic unity, despite their superficial differences. A more inclusive interpretation of the relationship between text and image belies the relationship between part and whole in Gauguin's work of art or oeuvre. It is through this comprehensive methodology that a greater perspective can be obtained with respect to Paul Gauguin's art and his interest in spirituality and identity.

The questions Gauguin asked reveal his conflicting identities and his search for meaning and status on and off his canvas. His ambiguous position on culture and society led him to ask philosophical and religious questions throughout his career. Gauguin's restlessness led him to take on the role of other individuals in his self-portrait as a means of defining his own identity. Although Paul Gauguin played many roles in his pursuit of selfishness, his greatest role was as a modern artist, constantly doubting and questioning the principles of order of existence and meaning in his life and work. In his final years, Gauguin wrote: "For most people, I will always be a mystery, I realize that people will understand me less and less... No matter what, I assure you that I will achieve first-class things. I can feel it and we'll see. "Gauguin's predictions turned out to be accurate. In 1906, three years after his death, his works were exhibited at the Salon d 'Aotomne, where his fame and popularity began.

\section{References}

Becker, Christopher. Paul Gauguin: A Journey to Tahiti. Edited by Christopher Wynne. Translated by Rosie Jackson. New York: Prestel Verlag, 2001.

Biddle, George. Tahitian Journal. Minneapolis: University of Minnesota Press, 1968.

Benedetti, María Teresa (2007), "Paul Gauguin and Italy." In Stephen F. Eisenman, Paul Gauguin: Artist of Myth and Dream. New York: Rizzoli International Publications

Bruce, Lawrence (2006), The Qur'an: A Biography, New York: Atlantic Monthly Press

Camiscioni, Sara Ann (2014), Buddhist imagery in the work of Paul Gauguin: The impact of primitivism, theology and cultural studies. Unpublished master thesis Faculty of the University of Missouri-Kansas City

Childs, Elizabeth (2001), "Seeking the Studio of the South: Van Gogh, Gauguin and Avant Garde Identity" in Cornelia Homburg, ed., Vincent van Gogh and the Painters of the Petit Boulevard. St. Louis, MO: Saint Louis Art Museum

Churton, Tobias, Gnostic Philosophy: From Ancient Persia to Modern Times. Rochester, VT: Inner Traditions, 2005.

Crooke,W., “The Legends of Krishna,” Folklore 11 No. 1. 142. March 1900: 3.

Danielsson, Bengt (1966), Gauguin in the South Seas. Translated by Reginald Spink. New York: Doubleday \& Company Inc.

Durkheim, Emile (1995), The Elementary Forms of Religious Life. Translated by Karen E. Fields, New York: The Free Press.

Eisenman, Stephen F. Ed. (2007), Paul Gauguin: Artist of Myth and Dream. New York: Rizoli International Publications. 
Eisenman, Stephen F. Ed. (2007), Gauguin's Skirt. New York: Thames and Hudson.

Fisk, Jehanne Teilhet (1983), Paradise Reviewed: An Interpretation of Gauguin's Polynesian Symbolism. Ann Arbor, MI: UMI Research Press, 1983.

Garraghan, G. J. (1957). A Guide To Historical Method. New York: Fordham University Press

Gauguin, Paul (1947) Noa Noa: my voyage to Tahiti, New York: Lear

Godeau, Abigail Solomon (1989), "Going Native: Paul Gauguin and the Invention of Primitive Modernism," Art in America 77 (July 1989): 118-129

Hellmich, Cristina et al. (2018), Gauguin: A Spiritual Journey. Prestel

Iswahyudi (2020), Toward Remediation of Indonesian New Fine Arts. Britain International of Linguistics, Arts and Education (BIoLAE) Journal Vol. 2, No. 3, November 2020 : 797-809 DOI: https://doi.org/10.33258/biolae.v2i3.332

Jansen, Leo, Hans Luijten, and Nienke Bakker (2007), Vincent Van Gogh: Painted with Words: The Letters to Émile Bernard. New York: Rizzoli in association with The Morgan Library \&Museum, New York, Van Gogh Museum, Amsterdam. Amsterdam: Van Gogh Museum

Lindstrom, Lamont (1990), Knowledge and Power in a South Pacific Society. Washington DC: Smithsonian Institution Press.

Loti, Pierre (Julien Vaurd), The Marriage of Loti (Rarahu), Translated by Clara Bell. London: T. Werner Laurie Ltd.

Moerenhout, J.A. Voyages aux îles du Grand Océan. Vol. 1-2. Paris: Bertrand, 1837.

Saidi, Acep Iwan et al. (2021), Narrative Patterns in Indonesian Fine Art. Britain International of Linguistics, Arts and Education (BIoLAE) Journal Vol. 3, No. 1, March 2021, Page: 77-87 DOI: https://doi.org/10.33258/biolae.v3i1.411

Semkiw, Walter (2008), Born Again: Kasus Reinkarnasi Tokoh dan Selebriti. Translated by Tasfan Santacitta. Awareness Publication

Shemsu'Din Ahmed, El Eflaki (1976), Legends of the Sufis: Selected Anecdotes from work entitled, The Acts of the Adepts (Menaqibu 'l'arifin). Translated by James W. Redhouse. London: The Theosophical Publishing House Ltd.

Silverman, Debora (2000), Van Gogh and Gauguin: The Search for Sacred Art. New York: Farrar, Straus and Giroux.

Swindle, Stephanie (2010), Paul Gauguin and Sprirituality. Unpublished master thesis The Graduate School College of Arts and Architecture, The Pennsylvania State University

Wasiutynski, Vojtech Jirat (1987), "Paul Gauguin's Selfportrair with Halo and Snake: The Artist as initiate and magus", Art Journal 46, No. 1, Mysticism and Occultism in Moedern Art. Spring, 1987: 22-28.

Young, Robert J.C (1995), Colonial desire: hiybridity in theory, culture, and race. New York: Routledge.

Zink, Marry Lynn (1978), "Gauguin's Poemes barbares and the Tahitian Chant of Creation". Art Journal 38, No. 1: 18-21 (Autumn, 1978).

Swindle, Stephanie (2010), Paul Gauguin and Sprirituality. Unpublished Master Thesis the Graduate School College of Arts and Architecture, The Pennsylvania State University. 


\section{List of Figures}

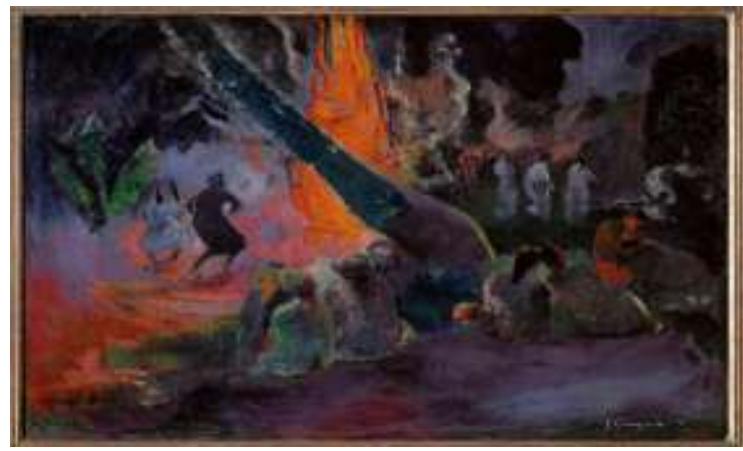

Figure 1. Paul Gauguin, Upaupa, 1891. Oil on canvas, 283/4 x 361/4 in. (73 x $92 \mathrm{~cm})$. W433. The Israel Museum, Jerusalem

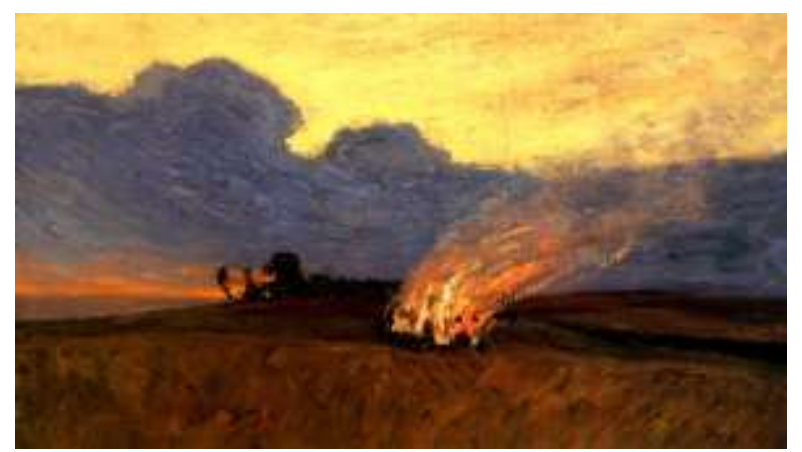

Figure 2. Paul Gauguin, Fire of Joy, 1891. Oil on canvas. 12 1/4 $x 18$ in. (31 $x 46 \mathrm{~cm})$. Santa Monica Museum of Art, Santa Monica, CA

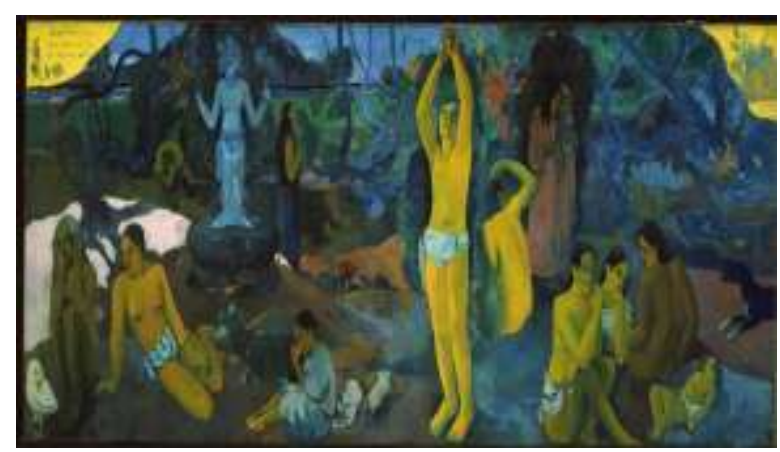

Figure 3. Paul Gauguin, Where Do We Come From? What Are We? Where Are We Going? 1897. Oil on canvas, 54 3/4 $\times 147$ 1/2 in. (139.1 × 374.6 cm). Museum of Fine Arts, Boston, Tomkins Collection

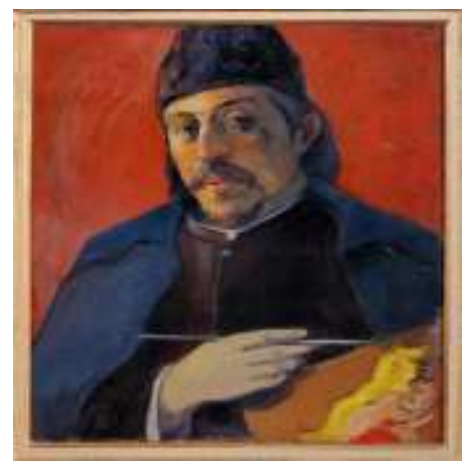

Figure 4. Paul Gauguin, Self-Portrait with Palette, 1894. Oil on canvas, $361 / 4 \times 28$ 3/4 in. (55 $x 46 \mathrm{~cm})$ 


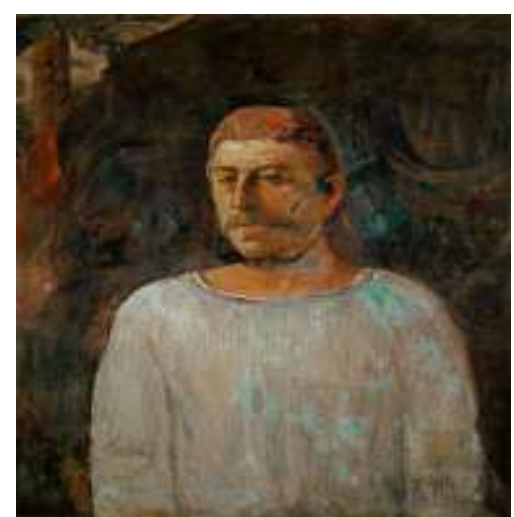

Figure 5. Paul Gauguin, Self-Portrait, Nearing Golgotha, 1896. Oil of canvas, $30 \times 25$ 1/4 in. (76 $x$ $64 \mathrm{~cm})$. Museu de Arte de São Paulo Assis Chateaubriand, São Paulo, Brazil

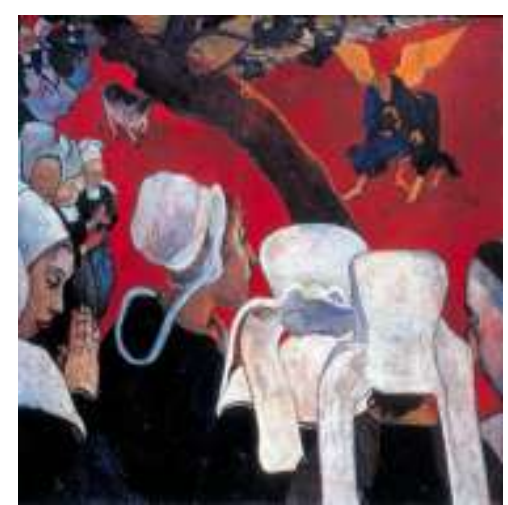

Figure 6. Paul Gauguin, Vision after the Sermon (Jacob Wrestling with the Angel), 1888. Oil on canvas, 38 3/4 $\times 36$ 1/4 in. (73 $\times 92 \mathrm{~cm})$. National Gallery of Scotland, Edinburgh

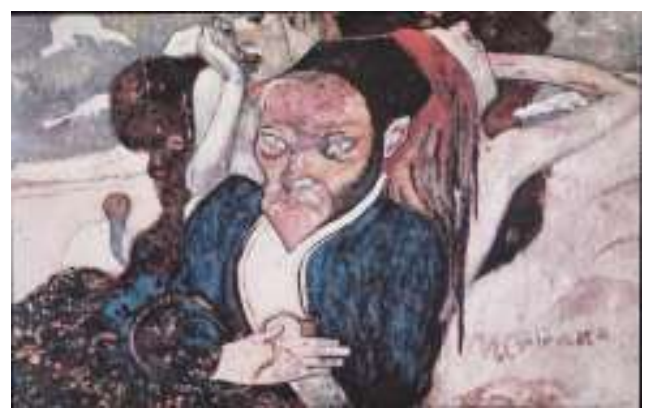

Figure 7. Paul Gauguin, "Nirvana": Portrait of Meyer de Haan, 1890. Oil and turpentine on silk, $73 / 4 \times 11 \frac{1}{2}$ in. $(20 \times 29 \mathrm{~cm})$. Wadsworth Atheneum, Hartford, CT. The Ella Gallup Sumner and Mary Catlin Sumner Collection Fund

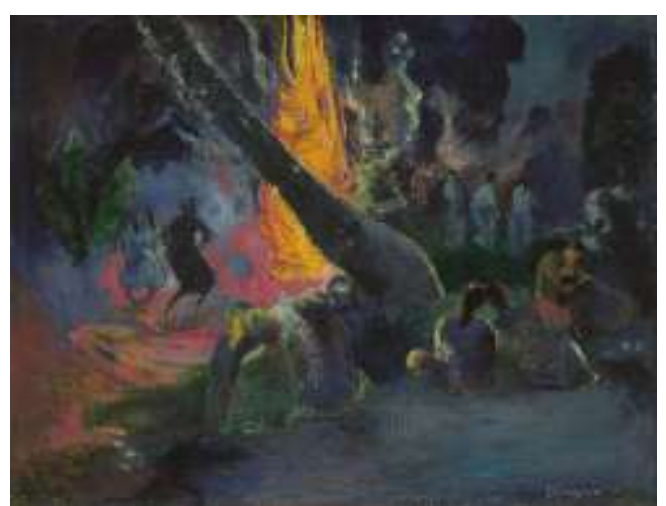

Figure 8. Upa Upa (https;/www.imj.org) 


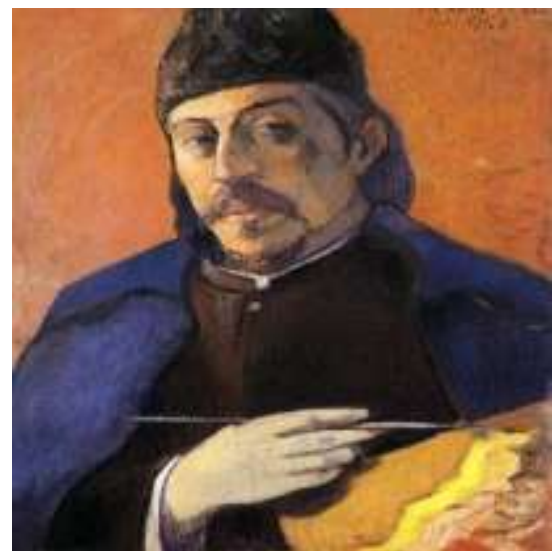

Figure 9. Self Portrait with a Palette 1894 (https://www.gauguin.org)

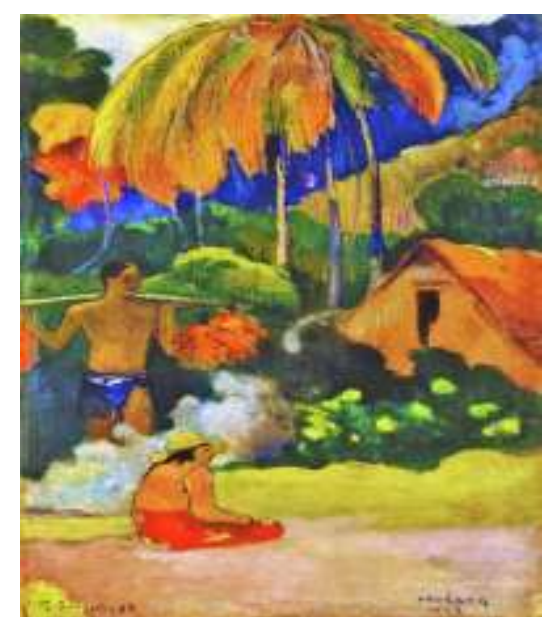

Figure 10. Landscape in Tahiti II (https://artsandculture.google.com) 